\title{
Lupus anticoagulant activity of some antiphospholipid antibodies against phospholipid bound $\beta_{2}$ glycoprotein I
}

\author{
D M Keeling, A J G Wilson, I J Mackie, D A Isenberg, S J Machin
}

\begin{abstract}
Aims-To determine whether $\beta_{2}$ glycoprotein I $\left(\beta_{2}\right.$ GPI) dependent anticardiolipin (aCL) antibodies detected in solid phase enzyme linked immunosorbent assays can also have lupus anticoagulant activity.

Methods-Six anticardiolipin antibodies were affinity purified from patients with these antibodies and lupus anticoagulant activity in their plasma.

Results-The anticardiolipin antibodies bound only to anionic phospholipids in the presence of $\beta_{2}$ GPI and bound to $\beta_{2}$ GPI in the absence of phospholipids. Four out of six had lupus anticoagulant activity in the dilute Russell viper venom time test.

Conclusions-The results show that some $\beta_{2}$ GPI dependent aCL are lupus anticoagulants. It is unclear why only some should have lupus anticoagulant activity while others do not.
\end{abstract}

(F Clin Pathol 1993;46:665-667)

Antibodies to phospholipid (aPL) are identified clinically in two different ways, either as immunoglobulins reacting with cardiolipin (aCL) or as lupus anticoagulants. The former antibodies are usually detected in solid phase enzyme linked immunosorbent assays (ELISA), the latter by their ability to prolong phospholipid dependent coagulation tests, the so-called lupus anticoagulants. Whether these tests detect distinct groups of antibodies or whether some antibodies have both activities has been debated for some time. In 1990 three groups of workers independently found that some aCL would bind only to anionic phospholipids in the presence of $\beta_{2}$ glycoprotein I $\left(\beta_{2} \mathrm{GPI}\right)$, a plasma protein known to bind to anionic phospholipids. ${ }^{1-3}$ The following year it was suggested that lupus anticoagulants bind only to phospholipids in the presence of human prothrombin, ${ }^{4}$ though in a later study the same group found that some

Table 1 Patient details

\begin{tabular}{llll}
\hline Case No & SLE & Thrombosis & $\begin{array}{l}\text { Episodes of } \\
\text { fetal loss }\end{array}$ \\
\hline 1 & No & Yes & 1 \\
2 & No & Yes & Male \\
3 & Yes & Yes & None \\
4 & Yes & Yes & None \\
5 & No & Yes & 1 \\
6 & No & No & 2 \\
\hline
\end{tabular}

aCL have lupus anticoagulant activity which depends on $\beta_{2}$ GPI. ${ }^{5}$ Two recent reports, one using whole plasma ${ }^{6}$ and one using total $\mathrm{IgG},{ }^{7}$ showed that lupus anticoagulant activity depends on $\beta_{2}$ GPI.

\section{Methods}

Six patients were studied; their details are shown in table 1. Two fulfilled the American Rheumatism Association's revised criteria for the classification of systemic lupus erythematosus (SLE). ${ }^{8}$ Case 1 had a leg vein thrombosis and a retinal vein thrombosis, cases $2-4$ all had recurrent leg vein thromboses, and case 5 had multiple pulmonary emboli. Three of the five female patients had sustained fetal loss, but none more than two episodes.

The following were obtained: cardiolipin, phosphatidylserine, and bovine serum No B-2771 (ABS) (Sigma Chemical Company Ltd, Poole, Dorset); gelatine from $\mathrm{BDH}$ Laboratory Supplies, Poole, Dorset; protein G, S sepharose fast flow, heparin sepharose, and sephacryl S200 HR from Pharmacia, Milton Keynes. The reagents used in the dilute Russell viper venom test (DRVVT) were from Unicorn Diagnostics Ltd, London. The microtitre plates used were Immuno Plate II, Maxisorp, Nunc, Denmark.

The method of McNeil et al was used for cardiolipin affinity chromatography, though with step rather than gradient elution. ${ }^{1}$ The cardiolipin affinity column was equilibrated

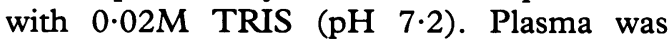
diluted 1 in 5 with this buffer and applied to the column. After washing, bound protein was eluted with $0.02 \mathrm{M}$ TRIS $/ 0.75 \mathrm{M} \mathrm{NaCl}$ (pH 7.2). The eluate from these columns has already been shown to be phospholipid free by incorporating radiolabelled phospholipid into the column and examining the eluate for radioactivity. ${ }^{9}$

To affinity purify aCL, $10 \mathrm{ml}$ plasma from the six patients was chromatographed on the cardiolipin affinity column. The protein eluted was dialysed against $0.02 \mathrm{M}$ TRIS $(\mathrm{pH}$ $7 \cdot 2)$; the dialysate was passed through a heparin sepharose column and straight on to a protein $\mathrm{G}$ column. IgG was eluted off the protein $\mathrm{G}$ with $0 \cdot 1 \mathrm{M}$ glycine/ $\mathrm{HCl}(\mathrm{pH} 7 \cdot 2)$. The antibodies were concentrated in $0.02 \mathrm{M}$ TRIS/0.15M NaCl (pH 7.4) using an Amicon Mini-Ultrafiltration Cell with a PM30 membrane to $0.2 \mathrm{~g} / \mathrm{l}$, assuming an extinction coefficient of 13.6 at $280 \mathrm{~nm}$ for a $1 \%$ solution.

In our modified DRVVT $0.1 \mathrm{ml}$ affinity

\footnotetext{
Department of

Haematology,

Addenbrooke's Hospital,

Hills Road, Cambridge

Accepted for publication

17 February 1993

Department o

niversity College and

A J G Wilson

Department of

Rheumatology

D A Isenberg
} 
Table 2 Absorbances in solid phase ELISAs with different coating antigens and different sample diluents

\begin{tabular}{|c|c|c|c|c|c|c|}
\hline \multirow[b]{2}{*}{$A P-a C L$} & \multicolumn{2}{|l|}{$C L$} & \multicolumn{2}{|l|}{$P S$} & \multicolumn{2}{|l|}{$\beta_{2} G P I$} \\
\hline & $A B S$ & Gelatine & $A B S$ & Gelatine & $A B S$ & Gelatine \\
\hline $\begin{array}{l}1 \\
2 \\
3 \\
4 \\
5 \\
6\end{array}$ & $\begin{array}{l}0.717 \\
1.433 \\
0.297 \\
0.392 \\
0.180 \\
0.228\end{array}$ & $\begin{array}{r}0.012 \\
0.004 \\
0.003 \\
-0.001 \\
0.005 \\
0.008\end{array}$ & $\begin{array}{l}0.694 \\
1.448 \\
0.395 \\
0.953 \\
0.283 \\
0.171\end{array}$ & $\begin{array}{l}0.004 \\
0.002 \\
0.004 \\
0.001 \\
0.003 \\
0.004\end{array}$ & $\begin{array}{l}1 \cdot 113 \\
1 \cdot 238 \\
1.301 \\
1.490 \\
1.400 \\
1 \cdot 378\end{array}$ & $\begin{array}{l}0.480 \\
0.500 \\
0.701 \\
0.864 \\
0.624 \\
0.589\end{array}$ \\
\hline
\end{tabular}

$\mathrm{CL}=$ cardiolipin, $\mathrm{PS}=$ phosphatidylserine,$\beta_{2}$-GPI $=\beta_{2}$-glycoprotein $\mathrm{I}, \mathrm{ABS}=$ adult bovine serum. replaced with $0.3 \%(\mathrm{w} / \mathrm{v})$ gelatine to exclude the bovine cofactor present in ABS. Some wells were coated with phosphatidylserine instead of cardiolipin; in each case $30 \mu \mathrm{l}$ of a $50 \mu \mathrm{g} / \mathrm{ml}$ solution in alcohol was added to each well and allowed to evaporate at $4^{\circ} \mathrm{C}$ overnight. Finally, some wells were coated with $30 \mu \mathrm{l}$ of a $500 \mu \mathrm{g} / \mathrm{ml}$ solution of $\beta_{2}$ GPI in TRIS-buffered saline instead of phospholipid.

\section{Results}

purified aCL (AP-aCL), or normal IgG, or buffer, was mixed with $0.1 \mathrm{ml}$ normal plasma and $0.1 \mathrm{ml}$ of dilute phospholipid reagent (or freeze thawed platelets); $0 \cdot 1 \mathrm{ml}$ viper venom was then added and after incubation for 30 seconds clotting was initiated by adding $0 \cdot 1$ $\mathrm{ml}$ of $25 \mathrm{mM} \mathrm{CaCl}$.

To purify $\beta_{2}$ GPI, plasma negative for aCL was chromatographed on the cardiolipin affinity column. The protein eluted was dialysed against $0.05 \mathrm{M}$ acetate/ $0.05 \mathrm{M} \mathrm{NaCl}(\mathrm{pH}$ $4 \cdot 8$ ). Cation exchange chromatography was then performed using a method modified from that of McNeil et al. ${ }^{1}$ The protein was applied to an $S$ sepharose fast flow cation exchange column $(1 \times 20 \mathrm{~cm})$. After washing, elution was carried out with a linear gradient from washing buffer to $0.05 \mathrm{M}$ acetate $/ 0 \cdot 65 \mathrm{M} \mathrm{NaCl}$ (pH 5.2). The peak eluting between $40 \%$ and $65 \%$ was collected and dialysed against $0.02 \mathrm{M}$ TRIS $(\mathrm{pH} 7 \cdot 2)$. The dialysate was applied to a heparin sepharose column $(1 \times 20 \mathrm{~cm})$ and then protein was eluted with $0.02 \mathrm{M}$ TRIS $/ 0.75 \mathrm{M} \mathrm{NaCl}(\mathrm{pH}$ $7 \cdot 2$ ). Finally, the sample was gel filtered on a sephacryl S200 HR column $(2 \times 100 \mathrm{~cm})$. The $\beta_{2}$ GPI was concentrated in $0.02 \mathrm{M}$ TRIS/ $0 \cdot 15 \mathrm{M} \mathrm{NaCl}$ (pH 7.4) using an Amicon Mini-Ultrafiltration Cell with a YM10 membrane, and the concentration estimated assuming an extinction coefficient at $280 \mathrm{~nm}$ of 9.4 for a $1 \%$ solution.

The standard aCL ELISA was based on that of Gharavi et $a l^{10}$ using $10 \%(v / v)$ ABS as the blocking agent and sample diluent. Blanks obtained from uncoated wells on the same plate were subtracted to account for non-specific binding. The reference serum was calibrated at 105 GPL against a standard prepared at an international workshop ${ }^{11}$; GPL being arbitrary units which were derived from the activity of an affinity purified serum. In the modified ELISA $10 \%(\mathrm{v} / \mathrm{v})$ ABS was
In all ELISAs non-specific binding was negligible - the highest absorbance in a blank well was 0.027 . None of the AP-aCL bound to cardiolipin or phosphatidylserine when gelatine was used as the diluent, but when $10 \%$ ABS was used all the antibodies bound strongly (table 2). For two of the antibodies the effect of adding $\beta_{2}$ GPI to the gelatine was studied and binding was restored in a dose dependent manner. ${ }^{12}$ When the wells were coated with $\beta_{2}$ GPI, all AP-aCL bound strongly in the absence of phospholipid (table 2).

The effects of the AP-aCL in the DRVVT along with their aCL titres are shown in table 3, along with the results for the corresponding plasmas. The DRVVT ratios for the AP-aCL are clotting time with the antibody divided by clotting time with buffer. Normal IgG had no effect on the clotting time. Four of the six AP-aCL prolonged the DRVVT (ratio of $>1 \cdot 1$ ), and in all four cases this prolongation was corrected with the freeze thawed platelets.

\section{Discussion}

Some regard solid phase ELISAs using anionic phospholipids and lupus anticoagulant tests as different ways of looking for the same antibodies. AP-aCL prepared using a liposome technique were found to possess lupus anticoagulant activity. ${ }^{13}$ Antibodies to phosphatidylserine (aPS) prepared using an affinity column, however, had no lupus anticoagulant activity. ${ }^{9}$ Furthermore, some patients have one activity and not the other, and in some patients with both activities these have been separated by chromatographic techniques. ${ }^{14}$ Bevers et al studied 16 patients with both aCL and lupus anticoagulant activity. ${ }^{4}$ In 11, aCL co-sedimented with cardiolipin liposomes leaving lupus anticoagulant activity in the supernatant fluid, but in

Table 3 aCL levels and DRVVT ratios with dilute phospholipid and freeze thawed platelets for patient plasmas and corresponding $A P-a C L$

\begin{tabular}{|c|c|c|c|c|c|c|c|}
\hline \multirow[b]{2}{*}{ Case No } & \multicolumn{2}{|c|}{$a C L(G P L)$} & \multicolumn{3}{|c|}{$D R V V T$ plasma } & \multicolumn{2}{|c|}{$D R V V T A P-a C L$} \\
\hline & Plasma & $A P-a C L$ & Phospholipid & $50: 50+$ & Platelets & Phospholipid & Platelets \\
\hline $\begin{array}{l}1 \\
2^{\star} \\
3 \\
4 \\
5 \\
6 \\
\text { Normal IgG }\end{array}$ & $\begin{array}{r}348 \\
177 \\
21 \\
171 \\
97 \\
36\end{array}$ & $\begin{array}{r}139 \\
135 \\
33 \\
110 \\
38 \\
23\end{array}$ & $\begin{array}{l}1 \cdot 90 \\
2 \cdot 10 \\
1 \cdot 78 \\
1 \cdot 34 \\
1 \cdot 54 \\
1 \cdot 24\end{array}$ & $\begin{array}{l}1.72 \\
1.38 \\
1 \cdot 72 \\
1.34 \\
1.21 \\
1.25\end{array}$ & $\begin{array}{l}1.55 \\
2.00 \\
1.16 \\
1.03 \\
1.08 \\
1.09\end{array}$ & $\begin{array}{l}1.42 \\
1.53 \\
1.18 \\
1.34 \\
1.06 \\
0.94 \\
0.99\end{array}$ & $\begin{array}{l}0.92 \\
1.00 \\
1.06 \\
0.99 \\
0.93 \\
0.95 \\
1.00\end{array}$ \\
\hline
\end{tabular}

${ }^{\star}$ Receiving warfarin; KCT ratio with $20 \%$ patient plasma: $80 \%$ normal plasma 1.49 . tDRVVT ratio with phospholipid and $50 \%$ patient plasma: $50 \%$ normal plasma. 
five patients lupus anticoagulant activity cosedimented with the liposomes and the aCL. The authors showed that in six of the former patients the lupus anticoagulant IgG was directed against phospholipid bound human prothrombin. It was therefore initially proposed that $\mathrm{aCL}$ and lupus anticoagulants are antibodies to different phospholipid bound proteins $\left(\beta_{2}\right.$ GPI and human prothrombin, respectively). A recent further study of the five patients in which aCL and lupus anticoagulant activity co-sedimented, however, found that in these cases the aCL had lupus anticoagulant activity in the DRVVT and that this was dependent on $\beta_{2}$ GPI. ${ }^{5}$ Lupus anticoagulant activity in whole plasma was shown to be dependent on $\beta_{2}$ GPI in some cases, ${ }^{6}$ and total IgG from three patients with $\beta_{2}$ GPI dependent aCL had lupus anticoagulant activity only in the presence of $\beta_{2} \mathrm{GPI}^{7}$ In both these cases the plasma and the total IgG could have contained antibodies to lipid bound prothrombin, which would not be retained on a cardiolipin affinity column in the absence of calcium. We affinity purified six aCL which do not bind to cardiolipin or phosphatidylserine in the absence of $\beta_{2} \mathrm{GPI}$, but do in its presence, and which bind to $\beta_{2}$ GPI in the absence of phospholipid. Four of these six antibodies are detectable as lupus anticoagulants in the DRVVT. These results confirm that some aCL which require $\beta_{2}$ GPI as a cofactor are also lupus anticoagulants. This is supported by the finding that murine monoclonal antibodies of the IgGl subtype raised against human $\beta_{2}$ GPI have lupus anticoagulant-like activity, including a prolongation of the DRVVT. ${ }^{716}$

It seems likely, then, that both points of view may be correct: some lupus anticoagulants are the $\beta_{2}$ GPI dependent aCL detected in solid phase ELISAs; others are due to antibodies directed against phospholipid bound human prothrombin. Why some $\beta_{2}$ GPI dependent aCL should have lupus anti- coagulant activity while others do not is as yet unclear.

1 McNeil HP, Simpson RJ, Chesterman CN, Krilis SA. Anti-phospholipid antibodies are directed against a complex antigen that includes a lipid binding inhibitor of coagulation: $\beta^{2}$-Glycoprotein I (apolipoprotein $\mathrm{H}$ ) Proc Natl Acad Sci USA 1990;87:4120-4.

2 Galli $M$, Comfurius $P$, Maassen $C$, et al Anticardiolipin antibodies (ACA) directed not to cardiolipin but to a plasma protein cofactor. Lancet 1990;335:1544-7.

3 Matsuura E, Igarashi Y, Fujimoto M, Ichikawa K, Koike $T$. Anticardiolipin cofactor(s) and differential diagnosis of autoimmune disease. Lancet 1990;336:177-8.

4 Bevers EM, Galli M, Barbui T, Comfurius P, Zwaal RFA Lupus anticoagulant IgG's (LA) are not directed to phospholipids only, but to a complex of lipid-bound human prothrombin. Thromb Haemostas 1991;66: 629-32.

5 Galli M, Comfurius P, Barbui T, Zwaal RFA, Bevers EM. Anticoagulant activity of $\beta_{2}$-glycoprotein I is potentiated by a distinct group of anticardiolipin antibodies. Thromb Haemostas 1992;68:297-300.

6 Oosting JD, Derksen RHWM, Entjes TI, Bouma BN, de Groot PG. Lupus anticoagulant activity is frequently Groot PG. Lupus anticoagulant activity is frequently dependent on the presence
Haemostas 1992;67:499-50.

7 Roubey RAS, Pratt CW, Buyon J, Winfield JB. Lupus anticoagulant activity of autoimmune antiphospholipid antibodies is dependent upon $\beta_{2}$-glycoprotein $\mathbf{I}$. $\mathcal{F}$ Clin Invest 1992;90:1100-8

8 Tan EM, Cohen AS, Fries JF, et al. The 1982 revised criteria for the classification of systemic lupus erythematosus. Arthritis Rheum 1982;25:1271-7.

9 McNeil HP, Krillis SA, Chesterman CN. Purification of antiphospholipid antibodies using a new affinity method. Thromb Res 1988;52:641-8.

10 Gharavi AE, Harris EN, Asherson RA, Hughes GRV Anticardiolipin antibodies: isotype distribution and phospholipid specificity. Ann Rheum Dis 1987;46:1-6.

11 Harris EN, Gharavi AE, Patel SP, Hughes GRV Evaluation of the anticardiolipin antibody test: report of an international workshop held 4 April 1986. Clin Exp Immunol 1987;68:215-22.

12 Keeling DM, Wilson AJG, Mackie IJ, Machin SJ, Isenberg DA. Some "antiphospholipid antibodies" bind to $\beta_{2}$-glycoprotein I in the absence of phospholipid. $B r \mathcal{F}$ Haematol 1992;82:571-4.

13 Pengo V, Thiagarajan P, Shapiro SS, Heine MJ. Immunological specificity and mechanism of action of IgG lupus anticoagulants. Blood 1987;70:69-76.

14 Exner T, Sahman N, Trudinger B. Separation of anticardiolipin antibodies from lupus anticoagulant on a phospholipid polystyrene column. Biochem Biophys Res Commun 1988;155:1001-7.

15 McNeil HP, Chesterman CN, Krilis SA. Anticardiolipin antibodies and lupus anticoagulants comprise separate antibodies and lupus anticoagulants comprise separate antibody subgroups with different phospholipid

16 Arvieux J, Pouzol P, Roussel B, Jacob MC, Colomb MG Lupus-like anticoagulant properties of murine monoclonal antibodies to $\beta_{2}$-glycoprotein I. $\mathrm{Br} f$ Haemato 1992;81:568-73. 
aspects of MRSA. The chapters provide a comprehensive review of the subject, rang ing from historical aspects through microbiology, extent and mechanisms of resistance, laboratory methods for detection of resistance, epidemiology, treatment of infections, eradication of carriage and control and cost of outbreaks.

Inevitably, there is considerable overlap between chapters, which is at times irritating, although I did not find any contradictions. The standard of prose is also somewhat varied, and one chapter left me wondering whether the author was aware that there are journals published outside the USA. As is often the case with monographs, the real value in the book is that somebody else has done the literature search for you. Chapter references average in excess of 75 (range 27 to 134), allowing the reader to absorb the distilled view of the chapter author, and yet readily seek the source data. I'm still not sure what to do with the long term carrier who is blocking an acute bed and is denied entry to hostel care. Certainly worth a read, but at $£ 89 \cdot 75$, this is one for the library.

GEOFFREY L RIDGWAY

Urinary Cytology. Manual and Atlas. 2nd edn. P Rathert, S Roth, MS Soloway. (Pp 210; 196 figs; DM 186.00.) Springer. 1993. ISBN 3-540-53312-5

This revised edition is the work of several authors, mainly from German institutions. It deals with the lower urinary tract and urine cytology. The manual section starts with an interesting and delightfully illustrated history of urine examination up to recent landmarks including image analysis and immunocytochemistry. A comprehensive discussion on indications and applications follows, with careful assessment of advantages and limitations.

The information with regard to benign disorders, including inflammation and specific infections, ultrastructure (well illustrated with electron microphotographs), epidemiology and classification of tumours, is carefully documented with a wealth of detail. The relation between dysplasia and malignancy is carefully argued with regard to the difficulties and pitfalls of grading and the sources of error.

The chapter on working techniques is excellent, fully comprehensive, and accurate, with details of methods and techniques very clearly illustrated with line drawings.

The atlas starts with a helpful introduction on its organisation and use, emphasising the comparative aspects of cell appearances. This is a pertinent point and it works well. There are over 100 well chosen colour plates illustrating the diagnostic points. Although the grey or blue background in some (figs 9.53a, 9.60b, and $9.98 \mathrm{~b}$.) compromises the contrast, this is a minor criticism. The "icing on the cake" comes with the chapters devoted to DNA cytometry, immunocytochemistry, and erythrocyte morphology.

Overall, the book is, as one would expect, a meticulous and excellent state of the art. It is invaluable to every cytologist and clinician interested in cancer of the lower urinary tract.

ANNE MORSE

\section{Notices}

\section{The Wellcome Trust, London NW1 21 October 1993 \\ The Scientific Work of Martin Gardner}

The BMJ, Medical Research Council Environmental Epidemiology Unit, and the Medical Section of the Royal Statistical Society for Social Medicine are holding a one day conference to discuss the work of Martin Gardner, who died prematurely at the beginning of this year.

Contact: Gaby Shockley, BMJ, BMA

House, Tavistock Square, London WC1H 9JR. Tel 071-387 4499.

\section{2th International Convocation on Immunology \\ Transfusion Immunology and Medicine \\ Buffalo, New York, 14-18 May, 1994}

Presented by The Ernest Witebsky Center for Immunology, plenary sessions will focus on the topics: removal of infectious agents; testing for infectious agents; allotypes; immunological effects on blood transfusion; components and alternatives; transfusion strategies.

Open poster sessions on the theme will be offered. Approved for up to 24.5 hours of CME credit.

Contact: Dr RK Cunningham, Director, 433 Sherman Hall, SUNY at Buffalo, 3435 Main St, Buffalo, NY 14214-3078. Tel (716) 829-2848. Fax (716) 829-2158.

\section{ACP Locum Bureau}

The Association of Clinical Pathologists runs a locum bureau for consultant pathologists.

Applicants with the MRCPath who would like to do locums and anyone requiring a locum should contact The General Secretary, 221 Preston Road, Brighton BN1 6SA. Tel (0273) 561188 . Fax (0273) 541227

\section{Corrections}

Sincere apologies are extended to Dr D M Keeling et al for an error which appeared in their paper, Lupus anticoagulant activity of some antiphospholipid antibodies against phospholipid bound $\beta_{2}$ glycoprotein $I, f$ Clin Pathol 1993;46:665-7. The second sentence of the first paragraph should read: "The former antibodies are usually detected in solid phase enzyme linked immunosorbent assays (ELISA), the latter by their ability to prolong phospholipid dependent coagulation tests."

Our apologies to Dr B J Bain whose name was incorrectly spelt in a book review which appeared in $\mathcal{f}$ Clin Pathol 1993;46: 584. The book is Bone Marrow Pathology. 